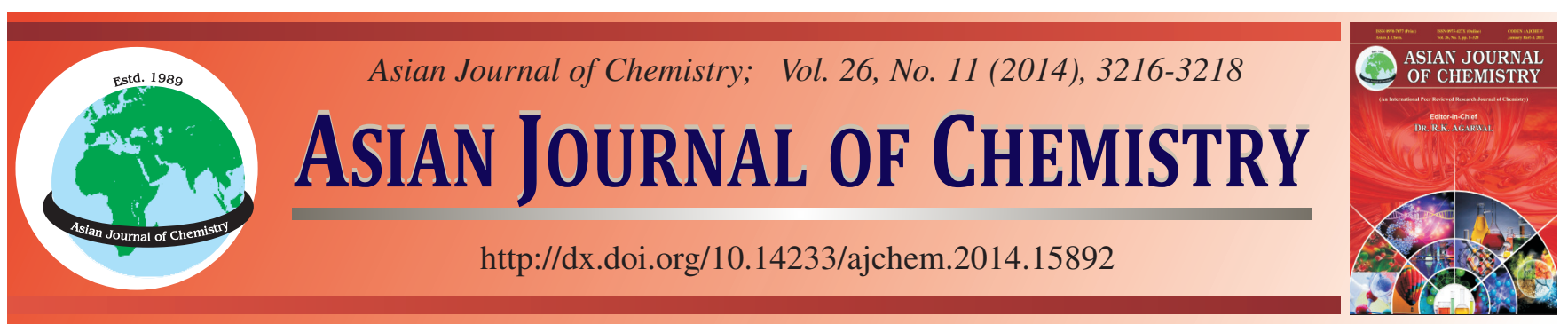

\title{
Synthesis, Crystal Structure and Antibacterial Activity of 2-(p-Tolyl)-5-(3,4,5-trimethoxyphenyl)-1,3,4-oxadiazole
}

\author{
XiAnPing Liu and DaOHANG HE*
}

School of Chemistry and Chemical Engineering, South China University of Technology, Guangzhou 510641, P.R. China

*Corresponding author: E-mail: cehdh@scut.edu.cn

Received: 11 June 2013;

Accepted: 1 October 2013;

Published online: 25 May 2014;

AJC-15216

The compound 2-( $p$-tolyl)-5-(3,4,5-trimethoxyphenyl)-1,3,4-oxadiazole (m.f. $\mathrm{C}_{18} \mathrm{H}_{18} \mathrm{~N}_{2} \mathrm{O}_{4}$ ) was synthesized and characterized by ${ }^{1} \mathrm{H}$ NMR, ${ }^{13} \mathrm{C}$ NMR, MS and X-ray single crystal diffraction analysis. In the crystal structure, the two phenyl rings and the 1,3,4-oxadiazole ring are nearly coplanar with the dihedral angles $4.55,1.13$ and $3.97^{\circ}$. There is an offset face-to-face $\pi$ - $\pi$ stacking interaction between $1,3,4-$ oxadiazole ring planes. The compound molecules are connected through the offset face-to-face $\pi$ - $\pi$ stacking interactions to generate a three-dimensional network. The results of preliminary biological activity assay showed that the title compound exhibited good antibacterial activity against Staphylococcus aureus and Escherichia coli.

Keywords: 1,3,4-Oxadiazole, Crystal structure, Synthesis, Antibacterial activity.

\section{INTRODUCTION}

The wide occurrence of the heterocycles in bioactive natural products and pharmaceuticals has made them as important synthetic targets. 1,3,4-Oxadiazoles are a class of heterocyclic compounds which have great importance in medicinal chemistry. During the last few decades, considerable attention has been devoted to the synthesis of 1,3,4-oxadiazole derivatives which have been found to exhibit diverse biological activities such as antibacterial ${ }^{1,2}$, antifungal ${ }^{3,4}$, antiinflammatory $^{5}$, analgesic ${ }^{6}$, anticonvulsant ${ }^{7}$ and insecticidal activities ${ }^{8-10}$. Moreover, substituted 1,3,4-oxadiazoles also revealed anticancer ${ }^{11,12}$ and tyrosinase inhibitory activities ${ }^{13,14}$. In this paper, 2-(p-tolyl)-5-(3,4,5-trimethoxyphenyl)-1,3,4-oxadiazole was efficiently synthesized by the condensation of 4-methylbenzohydrazide and 3,4,5-trimethoxy-benzaldehyde in ethanol solution with chloramine-T. Its crystal structure was determined by X-ray single crystal diffraction analysis. Furthermore, preliminary antibacterial activity against Staphylococcus aureus and Escherichia coli was investigated.

\section{EXPERIMENTAL}

All reagents were of analytical grade and used without further purification. Melting point was measured with an OPM100 OptiMelt apparatus and was uncorrected. ${ }^{1} \mathrm{H}$ NMR and ${ }^{13} \mathrm{C}$ NMR spectra were performed on a Bruker AVANCE$400 \mathrm{MHz}$ NMR spectrometer in $\mathrm{CDCl}_{3}$ with TMS as an internal standard. Mass spectrum was recorded on a Bruker Esquire HCTplus spectrometer (APCI).
General procedure: The title compound was synthesized according to Scheme-I. 4-Methylbenzohydrazide ( $1.50 \mathrm{~g}, 0.01$ mol) and 3,4,5-trimethoxybenzaldehyde (1.96 g, $0.01 \mathrm{~mol})$ were dissolved in ethanol $(50 \mathrm{~mL})$. The mixture was refluxed for $1 \mathrm{~h}$ until the starting materials disappeared (monitored by TLC) to give a clear white solution. Chloramine-T (14.08 g, $0.05 \mathrm{~mol}$ ) was added into the mixture and stirred for $4 \mathrm{~h}$ at $76^{\circ} \mathrm{C}$. Excess ethanol was evaporated under reduced pressure, the mixture was washed with water and filtered. Then, the crude product was recrystallized from acetone to give $2.5 \mathrm{~g}$ colorless crystals with a yield of $76.7 \%$. m.p. $192-193{ }^{\circ} \mathrm{C} ;{ }^{1} \mathrm{H}$ NMR (400 MHz, $\left.\mathrm{CDCl}_{3}, \mathrm{ppm}\right) \delta=8.00(\mathrm{~d}, J=8.1 \mathrm{~Hz}, 2 \mathrm{H}$, $\left.\mathrm{C}_{6} \mathrm{H}_{4}, 2,6-\mathrm{H}\right), 7.38$-7.25 (m, 4H, $\left.\mathrm{C}_{6} \mathrm{H}_{2}, 2,6-\mathrm{H} \mathrm{C}_{6} \mathrm{H}_{4}, 3,5-\mathrm{H}\right)$, 3.97 (s, 6H, $\left.\mathrm{OCH}_{3}\right), 3.93$ (s, 3H, $\left.\mathrm{OCH}_{3}\right), 2.42$ (s, 3H, $\left.\mathrm{CH}_{3}\right)$;<smiles>Cc1ccc(C(N)=O)cc1</smiles><smiles>COc1cc(C=O)cc(OC)c1OC</smiles>

$\mathrm{C}_{2} \mathrm{H}_{5} \mathrm{OH}$, ref, $1 \mathrm{~h}$

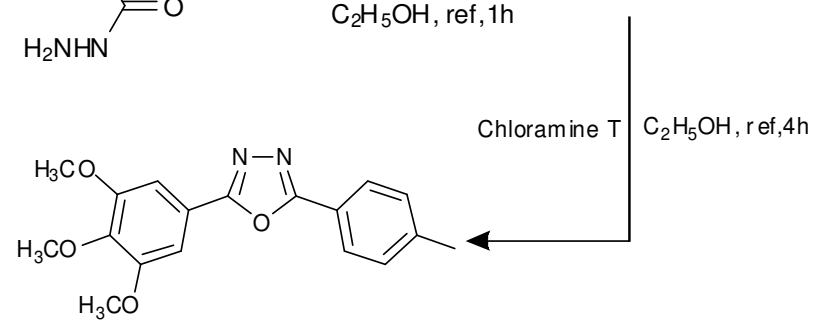

Scheme-I: Synthesis route of the title compound 
${ }^{13} \mathrm{C}$ NMR $\left(101 \mathrm{MHz}, \mathrm{CDCl}_{3}\right) \delta=164.60,164.20,153.65$, $142.25,141.13,129.72,126.82,121.05,119.03,104.18,60.96$, 56.38, 21.60. APCI MS: $m / z, 327.3(\mathrm{M}+1,100)$.

Determination of crystal structure: The colorless crystals were dissolved in ethanol. Single crystals suitable for X-ray analysis were obtained by slowly evaporation of the solvent. A colorless block crystal of the title compound with dimensions of $0.44 \mathrm{~mm} \times 0.42 \mathrm{~mm} \times 0.35 \mathrm{~mm}$ was selected for data collection which was performed on a Bruker Smart APEX 1000 CCD diffractometer equipped with a graphite-monochromatic $\operatorname{MoK}_{\alpha}$ radiation $(\lambda=0.71073 \AA$ ) by using a $\omega$ scan mode at 173(2) K. The structure was solved by direct methods with SHELXS-97 program ${ }^{15}$ and refined by full-matrix least-squares techniques on $\mathrm{F}^{2}$ with SHELXL-97 program ${ }^{16}$. All non-H atoms were refined anisotropically. All $\mathrm{H}$ atoms were placed in the geometrically idealized positions and allowed to ride on their respective parent atoms, with $\mathrm{C}-\mathrm{H}$ distance in the range of $0.9500-0.9800 \AA$ and $\mathrm{U}_{\text {iso }}(\mathrm{H})=1.2$ or $1.5 \mathrm{U}_{\text {eq }}(\mathrm{C} / \mathrm{O})$. All calculations were performed using the crystal structure crystallographic software package except for the refinement. The detailed crystal data, recording conditions and refinement results are listed in Table- 1 .

\begin{tabular}{ll}
\multicolumn{2}{c}{ TABLE-1 } \\
\multicolumn{1}{c}{ CRYSTAL DATA AND STRUCTURE REFINEMENT } \\
FOR THE TITLE COMPOUND
\end{tabular}

Determination of antibacterial activity: The antibacterial activity of title compound against $S$. aureus and E. coli were evaluated by the modified agar diffusion method ${ }^{17}$. The compound was dissolved in DMF. After encapsulation, autoclave sterilization at $121^{\circ} \mathrm{C}$ for $20 \mathrm{~min}$, nutrient agar was transferred to petri dish and frozen after cooling. After the test strains were spread on the solid nutrient agar surface, three stainless steel tubes $(7.8 \mathrm{~mm} \times 6 \mathrm{~mm} \times 10 \mathrm{~mm})$ were placed on the surface vertically, into which $100 \mu \mathrm{L}$ compound with certain concentration was injected. The inhibition was labeled as the diameter of transparent bacteriostatic circle after an incubation period of $24 \mathrm{~h}$ at $37^{\circ} \mathrm{C}$. Blank tests showed that DMF in preparing the test solutions does not affect the test organisms. All tests were repeated three times and average data were taken as the final result.

\section{RESULTS AND DISCUSSION}

The molecular structure of the title compound with atomic numbering is shown in Fig. 1. The structure of the title compound is in a triclinic crystal system with a $\mathrm{P} \overline{1}$ space group. The title compound contains two phenyl rings and a 1,3,4oxadiazole ring. The dihedral angle between the phenyl ring $(\mathrm{C}(3), \mathrm{C}(5)-\mathrm{C}(9))$ and $1,3,4$-oxadiazole ring is $4.55^{\circ}$, between the phenyl ring $(\mathrm{C}(4), \mathrm{C}(10)-\mathrm{C}(14))$ and 1,3,4-oxadiazole ring is $1.13^{\circ}$ and that between the phenyl ring $(\mathrm{C}(3), \mathrm{C}(5)-\mathrm{C}(9))$ and the phenyl ring $(\mathrm{C}(4), \mathrm{C}(10)-\mathrm{C}(14))$ is $3.97^{\circ}$. All these dihedral angles are so small that the three rings nearly construct a plane, providing a large conjugated system within the molecule. Selected bond lengths and bond angles are given in Table-2. The results reveal that the bond length of C(1)-N(2) and C(2)-N(1) are 1.2900(19) $\AA$ and 1.2882(19) $\AA$, which are between typical $\mathrm{C}-\mathrm{N}$ single bond $(1.47 \AA)$ and $\mathrm{C}=\mathrm{N}$ double bonds $(1.27 \AA)$. The $\mathrm{C}-\mathrm{C}$ bond lengths on the molecular skeleton are also between typical C-C single bond (1.54 $\mathrm{\AA}$ ) and $\mathrm{C}=\mathrm{C}$ double bonds ( $1.34 \AA$ ). This indicates that $\pi$-electrons in the molecular are delocalized. In this structure, there is an offset face-to-face $\pi$ - $\pi$ stacking interaction between $1,3,4$ oxadiazole rings with perpendicular distance $(3.3468(6) \AA)$ and centroid-centroid distance $(5.2629(9) \AA)$. The offset faceto-face $\pi-\pi$ stacking interactions link the molecule into a threedimensional network which further stabilizes the molecular structure.

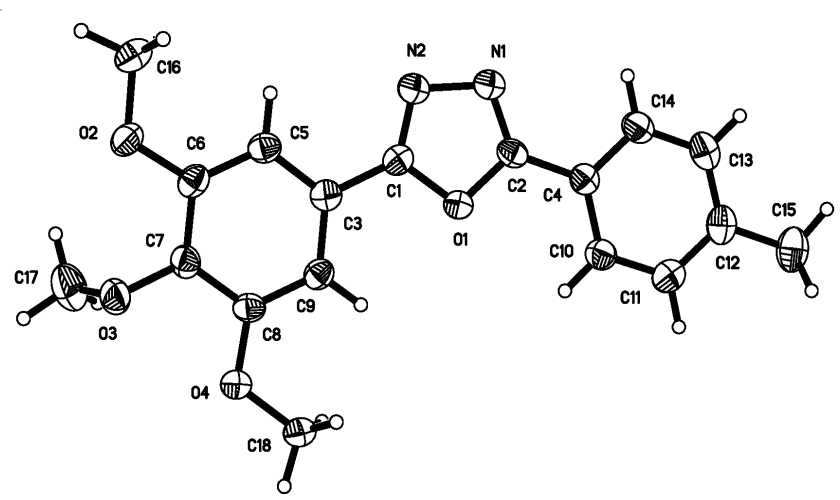

Fig. 1. Molecular structure of the title compound with $50 \%$ probability displacement ellipsoids

The antibacterial activity of the title compound was evaluated against $S$. aureus and E. coli. The test results are reported in Table-3. It can be observed that the title compound exhibits antibacterial activity against both test bacterial organisms. At the concentration of $5.0 \mathrm{mg} / \mathrm{mL}$, the title compound exhibits good antibacterial activity (inhibition zone diameter: $20.1 \mathrm{~mm}$ ) against $S$. aureus. The inhibition effect is strengthened with 


\begin{tabular}{|c|c|c|c|}
\hline \multicolumn{4}{|c|}{$\begin{array}{c}\text { TABLE- } 2 \\
\text { SELECTED BOND LENGTHS }(\AA) \text { AND BOND ANGLES }\left(^{\circ}\right) \text { FOR THE TITLE COMPOUND }\end{array}$} \\
\hline Bond & Lengths & Bond & Lengths \\
\hline $\mathrm{C}(1)-\mathrm{N}(2)$ & $1.2900(19)$ & $C(6)-C(7)$ & $1.4010(2)$ \\
\hline $\mathrm{C}(1)-\mathrm{O}(1)$ & $1.3645(17)$ & $\mathrm{C}(7)-\mathrm{O}(3)$ & $1.3735(17)$ \\
\hline $\mathrm{C}(2)-\mathrm{N}(1)$ & $1.2882(19)$ & $\mathrm{C}(10)-\mathrm{C}(11)$ & $1.3810(2)$ \\
\hline $\mathrm{C}(2)-\mathrm{O}(1)$ & $1.3700(16)$ & $C(11)-C(12)$ & $1.3920(2)$ \\
\hline$C(1)-C(3)$ & $1.4580(2)$ & $\mathrm{C}(12)-\mathrm{C}(13)$ & $1.3880(2)$ \\
\hline $\mathrm{C}(2)-\mathrm{C}(4)$ & $1.4510(2)$ & $C(12)-C(15)$ & $1.5030(2)$ \\
\hline$C(3)-C(5)$ & $1.3890(2)$ & $\mathrm{C}(16)-\mathrm{O}(2)$ & $1.4288(18)$ \\
\hline$C(4)-C(10)$ & $1.3910(2)$ & $\mathrm{C}(17)-\mathrm{O}(3)$ & $1.4230(2)$ \\
\hline $\mathrm{C}(5)-\mathrm{C}(6)$ & $1.3870(2)$ & $\mathrm{N}(1)-\mathrm{N}(2)$ & $1.4066(18)$ \\
\hline Bond & Angles & Bond & Angles \\
\hline $\mathrm{N}(1)-\mathrm{C}(2)-\mathrm{O}(1)$ & $112.39(12)$ & $C(5)-C(6)-C(7)$ & $120.36(13)$ \\
\hline $\mathrm{N}(1)-\mathrm{C}(2)-\mathrm{C}(4)$ & $128.26(13)$ & $\mathrm{O}(3)-\mathrm{C}(7)-\mathrm{C}(8)$ & $119.25(13)$ \\
\hline $\mathrm{O}(1)-\mathrm{C}(2)-\mathrm{C}(4)$ & $119.34(12)$ & $\mathrm{O}(3)-\mathrm{C}(7)-\mathrm{C}(6)$ & $120.78(13)$ \\
\hline $\mathrm{C}(5)-\mathrm{C}(3)-\mathrm{C}(9)$ & $121.34(13)$ & $C(8)-C(7)-C(6)$ & $119.80(13)$ \\
\hline$C(5)-C(3)-C(1)$ & $118.32(13)$ & $C(11)-C(10)-C(4)$ & $120.13(14)$ \\
\hline $\mathrm{C}(9)-\mathrm{C}(3)-\mathrm{C}(1)$ & $120.34(13)$ & $C(10)-C(11)-C(12)$ & $121.30(15)$ \\
\hline$C(10)-C(4)-C(14)$ & $119.00(14)$ & $\mathrm{C}(13)-\mathrm{C}(12)-\mathrm{C}(11)$ & $117.86(14)$ \\
\hline $\mathrm{C}(10)-\mathrm{C}(4)-\mathrm{C}(2)$ & $121.74(13)$ & $C(13)-C(12)-C(15)$ & $121.70(15)$ \\
\hline$C(14)-C(4)-C(2)$ & $119.25(13)$ & $\mathrm{C}(1)-\mathrm{N}(2)-\mathrm{N}(1)$ & $106.42(12)$ \\
\hline$C(6)-C(5)-C(3)$ & $119.01(13)$ & $\mathrm{C}(1)-\mathrm{O}(1)-\mathrm{C}(2)$ & $102.50(10)$ \\
\hline $\mathrm{O}(2)-\mathrm{C}(6)-\mathrm{C}(5)$ & $124.09(13)$ & $\mathrm{C}(6)-\mathrm{O}(2)-\mathrm{C}(16)$ & $116.77(12)$ \\
\hline $\mathrm{O}(2)-\mathrm{C}(6)-\mathrm{C}(7)$ & $115.54(13)$ & $\mathrm{C}(7)-\mathrm{O}(3)-\mathrm{C}(17)$ & $115.14(12)$ \\
\hline
\end{tabular}

\begin{tabular}{cccc}
\multicolumn{5}{c}{ TABLE-3 } \\
\multirow{2}{*}{ ANTIBACTERIAL ACTIVITY OF THE TITLE COMPOUND } \\
\hline \multirow{2}{*}{ Compound } & $\begin{array}{c}\text { Concentration } \\
(\mathrm{mg} / \mathrm{mL})\end{array}$ & Diameter of inhibition zone $(\mathrm{mm})$ \\
\cline { 3 - 4 } & 5.0 & S. aureus & E. coli \\
\hline \multirow{3}{*}{ Title } & 2.5 & 20.1 & 15.7 \\
compound & 1.25 & 18.3 & 14.3 \\
& 0.625 & 16.9 & 13.1 \\
& & 16.0 & 12.1 \\
\hline DMF & & 7.8 & 7.8 \\
\hline
\end{tabular}

the increase of the concentration in the test range. Besides, the title compound shows more abvious activity against $S$. aureus as compared to E. coli.

\section{ACKNOWLEDGEMENTS}

This work was supported by the Fundamental Research Funds for the Central Universities (2012ZM0035).

\section{REFERENCES}

1. K.K. Jha, A. Samad, Y. Kumar, M. Shaharyar, R.L. Khosa, J. Jain, V. Kumar and P. Singh, Eur. J. Med. Chem., 45, 4963 (2010).

2. K.H. Chikhalia, D.B. Vashi and M.J. Patel, J. Enzyme Inhib. Med. Chem., 24, 617 (2009).
3. R.R. Somani, P.Y. Shirodkar, M.P. Toraskar and V.J. Kadam, Indian J. Pharm. Educ. Res., 42, 53 (2008).

4. A. Rauf, S. Sharma and S. Gangal, Chin. Chem. Lett., 19, 5 (2008).

5. M.A. Bakht, M. Islam and A.A. Siddiqui, Indian J. Heterocycl. Chem., 15, 297 (2006).

6. X.J. Zou, L.H. Lai, G.Y. Jin and Z.X. Zhang, J. Agric. Food Chem., 50, 3757 (2002).

7. M. Amir and S. Kumar, Indian J. Heterocycl. Chem., 14, 51 (2004).

8. M.S.Y. Khan and M. Akhtar, Indian J. Chem., 42B, 900 (2003).

9. Z.K.A. El-Samii, J. Chem. Technol. Biotechnol., 53, 143 (1992).

10. W. Shi, X.H. Qian, G.H. Song, R. Zhang and R.P. Li, J. Fluor. Chem., 106, 173 (2000).

11. K.A. Milinkevich, C.L. Yoo, T.C. Sparks, B.A. Lorsbach and M.J. Kurth, Bioorg. Med. Chem. Lett., 19, 5796 (2009).

12. X.M. Zheng, Z. Li, Y.L. Wang, W.D. Chen, Q.C. Huang, C.X. Liu and G.H. Song, J. Fluor. Chem., 123, 163 (2003).

13. S. Cao, X.H. Qian, G.H. Song, B. Chai and Z.S. Jiang, J. Agric. Food Chem., 51, 152 (2003).

14. Y.C. Zhu, D.H. He and Z.R. Yang, Spectrochim. Acta A, 72, 417 (2009).

15. G.M. Sheldrick, SHELXS-97. Program for Crystal Structure Solution; University of Gottingen: Germany (1997).

16. G.M. Sheldrick, SHELXL-97. Program for Crystal Structure Refinement; University of Gottingen: Germany (1997).

17. X.L. Hu, X.Y. Xu, F.J. Yin and D.Q. Wang, Chin. J. Struct. Chem., 27, 733 (2008). 